\author{
Dr. sc. Vilma Pezelj, izvanredna profesorica \\ Marija Štambuk Šunjić, asistentica \\ Pravni fakultet Sveučilišta u Splitu
}

\title{
PRAVNI POLOŽAJ ŽENE PREMA SREDNJOVJEKOVNOM KORČULANSKOM STATUTU ${ }^{1}$
}

\author{
UDK: 342.7-055.5 \\ Primljeno: 10. 05. 2018. \\ Izvorni znanstveni rad
}

\begin{abstract}
Autorice analiziraju neka pitanja pravnog položaja žene u srednjovjekovnoj Korčuli, ukazujući na rješenja drugih dalmatinskih pravnih sustava. U radu su obrađena pitanja pravnog položaja žene u statusnom, obiteljskom, imovinskom, kaznenom i procesnom pravu. Težnja komunalnih vlasti ka sprečavanju prelaska imovine u ruke stranaca i sprečavanju diobe obiteljske imovine putem miraza temeljni su uzroci podređenog položaja žene u komunalnim pravnim sustavima. U Korčulanskom statutu vidljiva je slavenska pravna osnovica na koju se nadovezuju elementi bizantskog i mletačkog prava. U vrijeme recepcije rimskog prava počinju se usvajati neki elementi toga prava iz Justinijanove kodifikacije u glosatorskoj i postglosatorskoj obradi što ukazuje na postojanje interakcije pravnih kultura u srednjovjekovnim dalmatinskim komunama.
\end{abstract}

Ključne riječi: pravni položaj žene, Korčulanski statut, 13. stoljeće, dalmatinsko statutarno pravo.

\section{UVOD}

U komunalnim pravnim sustavima zadržale su se neke od brojnih javnopravnih i privatnopravnih restrikcija nametnutih ženama u pravnim porecima ranog srednjeg vijeka. ${ }^{2}$ Pravni je položaj žene u dalmatinskom statutarnom pravu lošiji od položaja muškarca, premda je svaki statut imao drugačiju pravnu regulativu. ${ }^{3}$

1 Rad je izložen na Međunarodnom znanstvenom skupu „Statut grada i otoka Korčule iz 1214. i njegovo povijesno i pravno značenje“, Korčula, 26. - 28. IX. 2014.

2 Ketch, P. - Kuhn, A., Frauen im Mittelalter, Band 2, Schwann, Düsseldorf, 1984., str. 146; Guerra Medici, M. T., I diritti delle donne nella societa` altomedievale, Edizioni Scientifiche Italiane, Napoli, 1986., str. 116; Dubby, G., Perrot, M., A History of Women in the West, Harvard University Press, Harvard, 1994., str. 174; Ennen, E., The Medieval Woman, John Wiey \& Sons, Limited, Oxford, 1989. , str. 29. O načelnoj izjednačenosti spolova u Justinijanovu razdoblju vidi: Besta, E., Le persone nella storia del diritto italiano, Padova, 1931., str. 33; Leicht, P. S., Storia del dirito italiano. Il diritto privato. Parte prima, Diritto delle persone e di famiglia, Giuffrè, Milano, 1941., str. 95; Kaser, M., Das Römische Privatrecht, II, München, 1975., str. 108-110.

3 U radu su korišteni sljedeći statuti: Brački statut $=$ Kadlec, K., Statutum et reformationes insulae Brachiae, Zagreb, 1926. Usp. i Cvitanić, A., Brački statut, Bračko srednjovjekovno pravo, Književni krug, Split, 2006. Isti: Srednjovjekovni statut bračke komune iz 1305., Brački zbornik, knjiga 7, Skupština općine Brač, Supetar, 1968. Budvanski statut = Ljubić, Š., Statuta et leges civitatis Buduae, civitatis Scardonae et 


\section{STATUSNO PRAVO}

U uvodu u potvrdu Korčulanskog statuta - starije redakcije ${ }^{4}$ stoji ,... da se Statut u upravo obnovljenom gradu ponovo donese da se na osnovi njega svatko može i bude dužan vladati i da (svatko), bez obzira na spol i na dob, jednako uživa

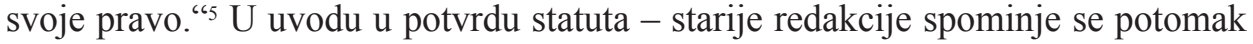
kneza i daje se mogućnost da to bude i žena. ${ }^{6}$

Statutarno pravo ne poznaje jedinstveni pojam punoljetnosti tj. ona je različita u pojedinim pravnim situacijama (skrbništvo, svjedočenje, nasljeđivanje). ${ }^{?}$

civitatis insulae Lesinae, MHJSM, JAZU, Zagreb, 1882./83. Usp. i Vučković, N., Srednjovjekovni statut Budve, Budva, 1988. Dubrovački statut = Bogišić, B., Jireček, K., Liber statutorum civitatis Ragusii, Zagrabie MCMIV. Usp. i Statut grada Dubrovnika, prev. Križman, M., Kolanović, J., Historijski arhiv Dubrovnik, Dubrovnik, 1990. Hvarski statut = v. pod Budvanski statut. Usp. i Cvitanić, A., Kasandrić, I., Hvarski statut, Književni krug, Split, 1991. Korčulanski statut = Hanel, J., Statuta et leges civitatis Curzulae, Zagreb, 1878. Usporedi: Statut grada i otoka Korčule, priredio i preveo Cvitanić, A., urednik Šeparović, Z., JAZU, Pravni fakultet, Skupština općine, Zagreb, Split, Korčula, 1987.; Usporedi i: Korčulanski statut: statut grada i otoka Korčule, Književni krug, Split, 1995.; Statut grada i otoka Korčule, priredio i preveo A. Cvitanić (ur. M. Foretić), Korčula, 2002. Kotorski statut = Statuta et leges civitatis Cathari, Venetiis, MDCXVI. Lastovski statut = Radić, F., Libro delli ordiamenti e delle usance della univesitade et dello comun della isola de Lagusta (Knjiga o uredbama i običajima skupštine i obćine otoka Lastova), Zagreb, 1901. Usp. Lastovski statut, priredio i preveo Cvitanić, A., Književni krug, Split, 1994. Mljetski statut $=$ Liber de ordinamenti e delle usanze der Insel Meleda, Arhiv für österreichische Geschichtsquellen, Wien, 1984., 1894., ed. Wenzel, G.; hrvatski prijevod Pucić, M., ,Statut oli zakoni od Universitati otoka Mljeta “, Dubrovnik - cvet narodnoga knjižtva, sv. III. Za 1851., Zagreb, 1852. (str. 193-218). Usp. Marinović, A., Veselić, I., Mljetski statut, Književni krug, Split, 2002. Paški statut = Statut Paške općine, Statuta Communitatis Pagi, MH Pag, Pravni fakultet Zagreb, Pag-Zagreb, 2011., Usp. Statuta communitatis Pagi, Venetiis, 1637. Rapski statut = Margetić, L., Strčić, P., Statut rapske komune iz 14. st., Adamić, Rab - Rijeka, 2004. Usp. Inchiostri, U., Galzigna, A, „Gli statuti di Arbe“, Archeografo Triestino, N. S., vol. 23, fasc. 1, str. 59-100, fasc. 2, str. 355-417, Trieste, 1899./1900. Skradinski statut = v. pod Budvanski statut; Usp. Birin, A., Statut grada Skradina, MH Skradin, Zagreb - Skradin, 2002. Splitski statut = Hanel, J., Statuta et leges civitatis Spalati, Zagreb, 1878. Usp. Cvitanić, A., Splitski statut: Splitsko srednjovjekovno pravo, Književni krug, Split, 1998. Detaljnije o izdanjima Splitskog statuta: Statut grada Splita, rukopisi i tiskana izdanja, katalog izložbe o sedamstotoj obljetnici 13122012., Književni krug, Split, 2012. Šibenski statut = Knjiga statuta, zakona i reformacija grada Šibenika, preveo Herkov, Z., pretisak izdanja Volvmen statvtorvm legvm, et reformationvm civitatis Sibenici cum tabula rubricarum, Venetiis, apud Nicolaum Morettum, 1608., Muzej grada Šibenika, Šibenik, 1982. Trogirski statut $=$ Strohal, I., Statuta et reformationis civitatis Tragurii, Zagreb, 1915. Usp. Berket, M., Cvitanić, A., Gligo, V., Statut grada Trogira, Split, 1988. Zadarski statut = Križman, M., Kolanović, J., Statuta Iadertina - Zadarski statut sa svim reformacijama odnosno novim uredbama donesenima do godine 1563., Matica Hrvatska Zadar i Hrvatski državni arhiv Zagreb, Zadar - Zagreb, 1997.

4 Statutarna materija Korčulanskog statuta sastoji se od statutarnih odredaba tzv. starije redakcije, novije redakcije, zbirke reformacija i katastika imanja Korčulanske općine. Starija redakcija ima uvod i 53 glave iz godine 1265. s dodatkom od još 20 glava iz godine 1271. Novija redakcija ima 157 glava. Iako u naslovu te glave stoji da su ti propisi doneseni 1214., riječ je o dopuni odredaba iz 1265 ., odnosno 1271. i o nizu novih odredba iz 14. i s početka 15. stoljeća (do godine 1432.) kronološki ispremiješanih. Zbirka reformacija sastoji se od 200 glava, tj. statutarnih izmjena bez kronološkog reda. Odnose se na prvu polovicu 15. st., premda ih ima iz vremena 14. st. Detaljnije: Cvitanić, A., „Korčulansko statutarno pravo“, u: Statut grada i otoka Korčule, priredio i preveo A. Cvitanić, (ur. M. Foretić) Korčula, 2002., str. $12-13$.

Korčulanski statut, str. 61.

6 Korčulanski statut, str. 62.

7 Usp. Beuc, I., ,Statut zadarske komune iz 1305. godine“, Vjesnik Državnog arhiva u Rijeci, sv. II, Rijeka, 1954., str. 579-580; Cvitanić, A., Statut grada Splita, Split, 1998., str. 148-150; Besta, E., Il diritto e le leggi civili di Venezia fino al dogado di E. Dandolo, str. 72-73; Roberti, M., Svolgimento storico del 
Punoljetnost se po odredbama Korčulanskog statuta stjecala sa 14 godina, za razliku od većine ostalih statuta i odredbi kanonskog prava.

U kaznenom se pravu žena do 14 godina načelno tretira kao i muškarac, ${ }^{8}$ dok se položaj odrasle žene u odnosu na odraslog muškarca kao počinitelja kaznenog djela pogoršava. ${ }^{9}$ Djeca (dječak i djevojčica) kažnjavaju se za nanošenje udaraca, ${ }^{10}$ odnosno za ubojstva, prema nahođenju kneza i Kurije. ${ }^{11}$

Maloljetnicima, maloumnicima i ženama nakon očeve smrti komunalna uprava postavljala je skrbnike. ${ }^{12}$

\section{1. U dalmatinskoj pravnoj regiji udana žena bila je ograničeno poslovno} sposobna. ${ }^{13}$ Po tom se pitanju dalmatinski statuti bitno razlikuju od rimskobizantskog i mletačkog prava i nalikuju karakteristikama langobardskog prava, što je razumljivo, uzme li se u obzir vremenska i prostorna blizina starohrvatskog i langobardskog prava na koju je i do sada u literaturi ukazivana pozornost. ${ }^{14}$

Neki statuti, npr. Dubrovački, izričito su propisivali podređenost žene mužu u svojim odredbama. Stoga u ugovorima koje zaključuju udane žene nalazimo termin „, cum consensu et voluntate mariti sui“ ${ }^{15}{ }^{15} \mathrm{Jačanjem} \mathrm{ekonomije} \mathrm{i} \mathrm{općinske} \mathrm{autonomije}$ i trgovačkim poletom koji zahvaća sve slojeve društva u 14. st., zahtijeva se nazočnost općinskih vlasti kod sudjelovanja žene u pravnim poslovima. ${ }^{16}$

Prema odredbama Korčulanskog statuta, poslovna sposobnost udane žene ograničena je naglašenom muževom vlašću, pa ona nije smjela zaključivati pravne poslove glede svoje imovine bez muževe suglasnosti, a kasnije niti bez sudjelovanja komunalne kurije. ${ }^{17}$ Statut posebno uređuje način otuđivanja imovine udanih žena.

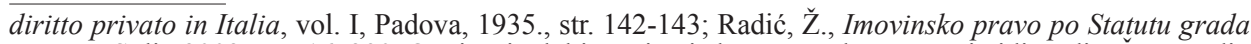
Trogira, Split, 2002., str. 16, 290. O utjecaju dobi na pitanje kaznene odgovornosti vidi Radić, Ž., nav. dj., str. 148., bilj. 126.

8 Korčulanski statut, gl. 50. star. red. i gl. 54. nov. red.

9 Korčulanski statut, gl. 13. nov. red.

10 Korčulanski statut, gl. 50. star. red. i 54. nov. red.

11 Korčulanski statut, gl. 2. nov. red.

12 Korčulanski statut, gl. 74. nov. red.

13 Margetić, L., Hrvatsko srednjovjekovno obiteljsko $i$ nasljedno pravo, Narodne novine, Zagreb, 1996., str. 180. Na to upućuju i talijanski znanstvenici glede talijanskih statutarnih propisa. Usp. Roberti, M., Svolgimento storico del diritto privato in Italia, vol. I, CEDAM, Padova, 1935., str. 136; Detaljnije: Bartulović, Ž. - Ignjatović, M., Widow enjoyment in Roman and Medieval Law (comparison with Venice, Frankish and „Istrian marriage"), The second International Balkan Conference for Roman Law and Roman Legal tradition „The Universality of Roman Law“, Ius Romanum 2/2017., str. 1-10.

14 Usp. Margetić, L., n. dj., str. 180.

15 Vidi opširnije u Pezelj, V., Pravni položaj žene prema statutarnom pravu srednjovjekovnih dalmatinskih komuna (doktorska disertacija), Split, 2003., str. 70 i dalje.

16 Najčešće kneza i kurije u Splitskom statutu (III, 72), Zadarskom statutu (II, 96), Trogirskom statutu (III, 23). Šibenskom statutu (IV, 26), Paškom statutu (IV, 18).

17 Korčulanski statut, gl. 140. i 143. nov. red.; gl. 9. Reformacija. 
Udana žena može otuđivati svoja dobra samo u tri slučaja, ${ }^{18}$ ne može tražiti ništa od očeve i majčine imovine ${ }^{19}$ niti poviše miraza. ${ }^{20}$

Ako muž umre ne oporučivši, a poslije njega ostanu žena i djeca, žena je imala pravo, ako i dalje ostane živjeti s djecom, na dolično uzdržavanje iz muževe ostavine.

\section{2. Udovica je u dalmatinskom statutarnom pravu imala povoljniji položaj od udane žene. Značajno je za njen položaj postojanje djece iz braka s ostaviteljem.}

Najčešće udovice imaju pravo uživanja nad dijelom koji je jednak dijelu jednog djeteta. Do majčine smrti djeca nisu mogla preuzeti imovinu, osim u slučaju majčine preudaje. ${ }^{21}$

Položaj žene u braku bez djece razlikuje se u pojedinim komunama. Najčešće ima ograničeno pravo uživanja koje se razlikuje u pojedinim komunama ili pak pravo na određeni novčani iznos za uzdržavanje. O visini prihoda odlučuje u Korčuli ${ }^{22}$ i u Skradinu ${ }^{23}$ kurija, u Šibeniku ${ }^{24}$ i Pagu $^{25}$ predstavnik vlasti s jednim rođakom. Ako imovina pokojnog supruga prelazi potrebe njegove udovice, kurija u punom sastavu dodjeljuje dio koji prelazi potrebe udovice njegovim najbližim srodnicima.

Po odredbama Korčulanskog statuta, udovica koja se želi ponovno udati može izdvojiti samo svoj miraz, a ako odluči ne udavati se više, može zadržati svoj miraz i svu muževu imovinu. ${ }^{26}$

Nešto veća prava imala je udovica iz braka bez djece na Braču i Hvaru gdje je dobivala u vlasništvo trećinu ostavine. ${ }^{27}$

18 Korčulanski statut, gl. 140. nov. red.

19 Korčulanski statut, gl. 98. nov. red.

20 Korčulanski statut, gl. 113. nov. red.

21 Korčulanski statut, gl. 38. star. red; gl. 42. nov. red; Dubrovački statut, IV; 7, VIII, 43; Mljetski 14, Lastovski 14; Kotorski 194, 198; Splitski, III, 36; Zadarski, II, 119, III, 122, 141; V, 26; Trogirski, III, 14; Šibenski II, 52, III, 59, V, 16, 30, 41; Brački I, 23, Skradinski 45; Budvanski 145. Usp. Čučković, V., „Materijalno obezbjeđenje supružnika u dubrovačkom srednjovjekovnom pravu“, Godišnjak Pravnog fakulteta u Sarajevu, XXVIII, 1980., str. 326-330, Beuc, I., Statut zadarske komune iz 1305. godine, Vjesnik Državnog arhiva u Rijeci, sv. II, Rijeka, 1954., str. 714; Detaljnije: Bogojević-Gluščević, N., „Legal regime of the property of married women in medieval Zeta littoral cities (Kotor, Budva, Shkoder)“, The second International Balkan Conference for Roman Law and Roman Legal tradition ,The Universality of Roman Law“, Ius Romanum 2/2017., str. 1-23.

22 Korčulanski statut, gl. 42. nov. red.

23 Skradinski statut, gl. 45.

24 Šibenski statut V, 30. Detaljnije: Pezelj, V., „Pravni položaj žene u srednjovjekovnom Šibeniku“, Zbornik radova „, Mustafa Imamović, 45 godina naučnog i publicističkog rada“, Posebna izdanja, Knjiga 6, Sarajevo/Gradačac, 2010., str. 175-198.

25 Paški statut V, 36.; Detaljnije: Pezelj, V., „Pravni položaj žene u Paškom statutu 1433.“, Anali Pravnog fakulteta u Beogradu, god. LVIII 1/2010., str. 168-194.

26 Korčulanski statut, gl. 38. star. red., gl. 42. nov. red.

27 Brački statut I, 23; Hvarski statut II, 32. 
Po odredbama Zadarskog statuta, ako nema oporuke ni djece, rođaci mogu otpremiti udovicu vrativši joj miraz, a uz miraz je i $10 \%$ muževe ostavine. ${ }^{28}$ Posebno valja istaknuti da će u tom slučaju dobiti $10 \%$ bez obzira na visinu miraza, što znači da se dio obračunava u odnosu na visinu muževe imovine što je dokaz približavanja bračnoj zajednici dobara. Ovaj se način razlikuje se od rimsko-bizantsko-mletačkog gdje udovica dobiva dio ovisan o visini miraza tj. bogatstvu svog oca. ${ }^{29}$

Preudajom udovica najčešće gubi pravo na muževu ostavinu premda joj neki statuti i tada priznaju pravo na vrstu otpremnine koja se spominje u Trogiru (ingannatio), Skradinu (enganacio) i Rabu (consuetudo sponcelatii). ${ }^{30} \mathrm{U}$ tim je komunama njen položaj puno bolji nego u južnim komunama koje znatno odstupaju od rimsko-bizantskog prava npr. u Dubrovniku ${ }^{31}$ i Kotoru ${ }^{32}$ gdje dobiva u vlasništvo samo prsten dobiven od muža prilikom zaruka. Slično je propisano na Lastovu ${ }^{33}$ i na Mljetu. ${ }^{34}$

Korčulanski statut pravno regulira i položaj udovca. Udovac ne smije ništa otuđiti od dobara preminule supruge bez odobrenja njenih najbližih srodnika. Svojoj djeci dužan je podjednako raspodijeliti majčina dobra ako ne žele s njim živjeti. ${ }^{35}$ Kćeri je dužan dati dio dote u trenutku udaje ili ako je odlučila samostalno živjeti. Ako nema potomaka s pokojnom suprugom, može zadržati njen miraz do ponovne ženidbe.

1. 3. Nazočnost robova u srednjovjekovnim komunama možemo pratiti od kraja 13. st. tj. od vremena naglog uspona gradova na jadranskoj obali i Mediteranu, što je dovelo do velike potrebe za radnom snagom, pa je trgovina robovima postala unosan posao. ${ }^{36}$ Zbog protivljenja Crkve, službeno se moglo

${ }_{28}$ Zadarski statut III, 41. Usp. Beuc, I., „Statut zadarske komune iz 1305. godine“, Vjesnik Državnog arhiva u Rijeci, sv. II, Rijeka, 1954., str. 594.; Pezelj, V., „Naznake pravnog položaja žene u sednjovjekovnom Zadru“, Zbornik radova Pravnog fakulteta u Splitu, god. 43 - br. 3-4/2006 (83), str. 523-551.

29 Margetić, L., „Mletačka repromissa, “dar u ponedjeljak” i grosina (pellicia vidualis)“, Zbornik radova Pravnog fakulteta u Zagrebu, XXIX, 1989., str. 169.

30 Trogirski statut, III, 14; Skradinski statut, gl. 45. Detaljnije: Margetić, L., Hrvatsko srednjovjekovno obiteljsko i nasljedno pravo, str. 171, 183; Pezelj, V., „Pravni položaj žene u srednjovjekovnom Rapskom statutu“, Zbornik radova Pravnog fakulteta u Splitu, god. 48 (2011.), broj 1 (99), str. 73-87.

31 Dubrovački statut IV, 8

32 Kotorski statut, gl. 151.

33 Lastovski statut, gl. 14; Detaljnije: Pezelj V. - Štambuk Šunjić, M.: „Pravni položaj žene po Lastovskom statutu“, Zbornik radova Pravnog fakulteta Split, br. 3/2013 (109), str. 529.

34 Mljetski statut, gl. 14; Detaljnije: Pezelj, V., „Pravni položaj žene prema Mljetskom statutu iz 1345. godine“, Liber amicorum, Zbornik radova posvećen Antunu Cvitaniću, Ž. Radić (ed.), Split, 2016. str. 324 .

35 Korčulanski statut, gl. 43. nov. red. Detaljnije: Dokoza, S., „Sustav dota u srednjovjekovnoj korčulanskoj komuni“", Godišnjak grada Korčule, 6., 2001., str. 33.

36 Usp. Perinčić, T., „Prodaja roblja na Jadranu u 17. stoljeću“, Miscellanea Hadriatica et Mediterranea, vol. 1, no. 1, 2013., str. 109-120; Tenšek, T. Z., Krstjani i trgovina robljem na Sredozemlju između 13. i 15. st., Fenomen „,Krstjani“ u srednjovjekovnoj Bosni i Humu, Sarajevo, 2005., str. 309-354; Petranović, B., O ropstvu po srpskim spomenicima $i$ statutima primorskih dalmatinskih gradova, Rad JAZU XVI, Zagreb, 1971.; Čremošnik, G., „Pravni položaj našeg roblja u srednjem veku“, GZM, n. s., knj. 2., Sarajevo, 1947., str. 69-73; Frejdenberg, M. M., „Srednjovjekovni dalmatinski grad i društveni tipovi“", Mogućnosti, Split, 1972., str. 86-101. 
Dr. sc. Vilma Pezelj i Marija Štambuk: Pravni položaj žene prema srednjovjekovnom Korčulanskom... Zbornik radova Pravnog fakulteta u Splitu, god. 55, 3/2018., str. 557.- 578.

trgovati samo krivovjercima, što se u praksi često izigravalo na različite načine. Roditelji su mogli prodati u roblje svoju djecu, muževi svoje žene, a u doba gladi bilo je i slučajeva samoprodaje u ropstvo. ${ }^{37}$ Notarski spisi ukazuju nam na mnogo veći broj žena u odnosu na muškarce u trgovini robljem..$^{38}$

Iako je u Dubrovniku 1416. ukinuta prodaja roblja, ostavljeni su mogućnost i pravo kupovanja roblja za vlastitu upotrebu. ${ }^{39}$ Odredba o zabrani trgovanja robljem unesena je u reformacije Korčulanskog statuta. Prema ref. 36. iz 1399., ropstvo nije potpuno ukinuto nego je samo ograničeno njegovo postojanje. Zabranjeno je trgovati robljem, ali se robove smjelo kupiti za svoje potrebe. Rob odnosno ropkinja nisu smjeli biti kršteni. Korčulanskom knezu dopušteno je kupiti ropkinje patarenke iz Bosne. ${ }^{40}$

Druga statutarna zabrana trgovanja robljem u ref. 141. pooštrava globu za Korčulane koji se budu bavili tom djelatnošću, nastojeći u potpunosti prekinuti trgovanje robljem. Smatra se da je nastala prije prosinca $1412 .{ }^{41}$

U notarskim zapisima nalaze se i slučajevi oslobađanja robova. Tako 27. ožujka 1301. Mira, udovica Lampredija Balislave s Korčule, oslobađa svoju robinju i njenog sina. ${ }^{42}$

Pravni se položaj robova mijenjao paralelno s mijenjanjem gospodarskih prilika i postupno evoluirao u status sluge. ${ }^{43}$ Po odredbama Korčulanskog statuta, nitko nije smio odvesti tuđeg slugu ili sluškinju bez dopuštenja njihova gospodara, a

37 Kancelariski i notariski spisi, ur. Čremošnik, G., Beograd, 1932., 457/ 117-118; Spisi dubrovačke kancelarije I = Spisi dubrovačke kancelarije, prepisao i prepremio G. Cremošnik; knjiga I, Zapisi notara Tomazina de Savere (1278-1282), Zagreb, 1951., 403/116. Spisi dubrovačke kancelarije II, prepisao i pripremio J. Lučić; knjiga II, Zapisi notara Tomazina de Savere (1282-1284), Zagreb, 1984., 322. DinićKnežević, D., Položaj žena u Dubrovniku u XIII i XIV veku, SANU, posebna izdanja, odeljenje istoriskih nauka, Beograd, 1974., str. 105.

38 Kancelariski $i$ notariski spisi (dalje KNS), ur. Čremošnik, G., Beograd, 1932., str. 37-179; Spisi dubrovačke kancelarije (dalje SDK) I, 82-84, 97, 99, 100, 116, 137, 164. Usp. Dinić-Knežević, D., nav. dj., str. 12 .

39 Lučić, J., Obrti i usluge u Dubrovniku do početka XIV. stoljeća, Zagreb, 1979., str. 136-159, sistematizira roblje i ostale djelomično zavisne osobe. Usp. Budak, N., „,Pravni položaj serva i famula u komunalnim društvima na istočnom Jadranu“, Radovi Instituta za hrvatsku povijest, Zagreb, 1986., str. 51-68; Blehova Čelebić, L., Žene srednjovjekovnog Kotora, Podgorica, 2002., str. 150.

40 Korčulanski statut, gl. 150. nov. red.

${ }^{41}$ Foretić, V., Otok Korčula u srednjem vijeku do god. 1420., Rad JAZU, Zagreb, 1940., str. 142. Detaljnije: Dokoza, S., Dinamika otočnog prostora, Split, 2009., str. 141-143.

42 Spisi dubrovačke kancelarije IV, Zapisi notara Andrije Beneše (1295-1301), Zagreb, 1993. $441 / 118$.

43 Roller, D., Dubrovački zanati u 15. i 16. st., Zagreb, 1951., str. 159-163; Mosher Stuard, S., A State of Deference: Ragusa / Dubrovnik in the Medieval Centuries (The Middle Ages Series), University of Pennsylvania Press, 1992., str. 120; Budak, N., „Pregled literature i objavljenih izvora o problemu serva i famula u srednjovjekovnim društvima na istočnom Jadranu“, Radovi IHP, 17., 1984., str. 5-34; isti: „Struktura i uloga obitelji serva i famula u komunalnim društvima na istočnom Jadranu“, Starohrvatska prosvjeta, 14, 1984., str. 347-360; isti: „Trgovina radnom snagom na istočnom Jadranu“, Starohrvatska prosvjeta, 14, 1984., str. 105-138. Usp. Ladić, Z., „Religioznost kao pokretač društvenih i intimnih promjena u srednjem vijeku - primjer dominacije „,socijalnog i laičkog kršćanstva“ u urbanim društvima istočnojadranske obale, Religiousity as the Impetus of Social and Intimate Changes in the Middle Ages“", 7. istarski povijesni biennale, sv. 7, Poreč, 2017., str. 93-96. 
kažnjavali su se oni koji bi primili slugu ili sluškinju koji su prije ugovorenog roka napustili svojega gospodara. ${ }^{44}$

\section{OBITELJSKO PRAVO}

Na obiteljsko pravo značajan su utjecaj imali kanonsko pravo, stara romanska tradicija i hrvatska kultura. ${ }^{45}$ Jasno se osjeća duh stare kućne zajednice i prevladava obiteljsko vlasništvo. Korčulanski statut propisuje da ,... otac jest i mora biti gospodar za svojega života, a majka (mora biti gospodarica) nakon smrti svojega muža. ${ }^{"}{ }^{4}$

2. 1. Bračno pravo. U dalmatinskom statutarnom pravu brak je bio temelj obitelji, a pravno relevantan bio je samo crkveni brak. Po odredbama reformacija Korčulanskog statuta bilo je zabranjeno uzeti za suprugu djevojku ili ženu bez privole njenih najbližih krvnih srodnika ${ }^{47}$ Nepostojanje dozvole roditelja u nekim se statutima smatralo bračnom smetnjom (impedimentum iuris). ${ }^{48}$

Reguliranje zabrane tajnih brakova u dalmatinskom statutarnom pravu uslijedilo je nakon IV. Lateranskog koncila iz 1215. g. kojim je Crkva željela uspostaviti dominantan utjecaj nad ustanovom braka, premda joj to nije posvuda uspijevalo. ${ }^{49}$

Ako izuzmemo najstariji oblik bračnog imovinskog prava, prisutan $\mathrm{u}$ Dubrovačkom i Kotorskom statutu koji predviđaju strogu separaciju pod utjecajem

44 Korčulanski statut, gl. 115. star. red.; gl. 94. nov. red.

45 Detaljnije: Cvitanić, A., „Korčulansko statutarno pravo“, u: Statut grada i otoka Korčule, priredio i preveo A. Cvitanić (ur. M. Foretić), Korčula, 2002., str. 37.

46 Korčulanski statut, gl. 42. star. red.; gl. 47. nov. red.

47 Korčulanski statut, gl. 151. Ref. Za Kotor usp. Blehova-Čelebić, L., Žene srednjovjekovnog Kotora, Podgorica, 2002., str. 24. O razbaštinjenju potomaka zbog nepoštovanja volje roditelja kod sklapanja braka u antici usp. Arjava, A., Women and Law in Late Antiquity, Clarendon Press, Oxford, 1996., str. 40.

48 Splitski statut, III, 124. O bračnim smetnjama vidi Leicht, P. S., n. dj., str. 60.

49 Usp. Čučković, V., O odredbi dubrovačkog statuta De concordio inter virum et uxorem schepatos (IV, 60), Godišnjak PF u Sarajevu, god. 25 (1977.), str. 448-449. Ova je odredba imala utjecaja i na dalmatinske statute. Lastovski statut govori o sklapanju brakova u gl. 74. - 76., uz napomenu da su te odredbe donesene 1449. na Zboru lastovske Zajednice. Detaljnije: Pezelj V. - Štambuk Šunjić, M.: „Pravni položaj žene po Lastovskom statutu“, Zbornik radova Pravnog fakulteta Split, br. 3/2013 (109), str. 527. 
Dr. sc. Vilma Pezelj i Marija Štambuk: Pravni položaj žene prema srednjovjekovnom Korčulanskom... Zbornik radova Pravnog fakulteta u Splitu, god. 55, 3/2018., str. 557.- 578.

slavenskog prava, te statute Raba ${ }^{50}$ i Paga ${ }^{51}$ koji izričito predviđaju zajednicu stečene imovine, većina ostalih statuta na različite se načine približava idejama bračne zajednice dobara.

$\mathrm{Na}$ Korčuli se ženina imovina sastojala od njena miraza, pa ako se u slučaju udovištva odlučila preudati, smjela je uzeti samo svoj miraz, a ostalu imovinu ostaviti muževim potomcima. ${ }^{52}$

Pod utjecajem kanonskog prava davanje miraza postaje obvezno. ${ }^{53}$ Kao jedine iznimke mogli bismo spomenuti Rapski i Paški statut, koji ostavljaju mogućnost da oba supružnika uđu u brak bez miraza, te Šibenski statut, o čemu saznajemo iz isprave vođene 1292 . godine..$^{54}$

O predaji miraza redovito se sastavljala javna isprava, tzv. carta dotis, o čemu postoji mnoštvo primjera u notarskim spisima. Prema statutarnoj odredbi iz 1412. godine, potebno je o svakom mirazu sastaviti javnu ispravu u roku od jedne godine, pod prijetnjom kazne..$^{55}$ Navođenje termina do godine dana nakon sklapanja braka upućuje na postojanje ustaljene prakse da se miraz daje nakon vjenčanja, što je pogodovalo mogućnosti izbijanja sporova. ${ }^{56} \mathrm{U}$ ispravi o mirazu (carta dotis) najčešće se navode imena supružnika i osobe koja daje miraz (persona dotans), nadnevak

50 Rapski statut, II, 14. Na Rabu je postojala imovinska zajednica ograničena na stečena dobra samo ako je žena unijela u brak barem ikakvu imovinu ili ako oboje u trenutku sklapanja nisu ništa posjedovali. Valja naglasiti da je staro pravo Raba poznavalo univerzalnu zajednicu. Detaljnije: Pezelj, V., „Pravni položaj žene u srednjovjekovnom Rapskom statutu“, Zbornik radova Pravnog fakulteta u Splitu, god. 48 (2011.), broj 1 (99), str. 73-87. Usp. Margetić, L., „Iz starije pravne povijesti Raba“ u: Istra i Kvarner, izbor studija, Rijeka, 1996., str. 254. Nakon što je univerzalna zajednica evoluirala u zajednicu stečenih dobara, u takvom je obliku izvršila utjecaj na Paški statut, pored osorskog prava koje je također imalo utjecaja na paški pravni sustav. Vlasništvo nad otokom Pagom naizmjenično je pripadalo Rabljanima i osorskim knezovima. Usp. Codex diplomaticus, Supplementa, vol. I-II, Zagreb, 1998., 37/75, 38/74, 40/77, 55/94.

51 Paški statut V, 44. Na Pagu žena ima pravo na stečena dobra ako je ušla u brak bez miraza i ako u braku nije bilo djece. Paški statut V, 44. Detaljnije: Pezelj, V., „Pravni položaj žene u Paškom statutu 1433.“, Anali Pravnog fakulteta u Beogradu, god. LVIII 1/2010., str. 168-194.

52 Korčulanski statut, cap 38. star. red.; cap. 42 nov. red. Slično je bilo i u Dubrovniku (Dubrovački statut IV, 59), što ukazuje na to da je ,dalmatinsko bračno imovinsko pravo u svojoj osnovi slavensko pravo što je vladalo na kontinentu nasuprot dalmatinskim otocima i oko gradskog teritorija dalmatinskih gradova.“ Margetić, L., „Bizantsko bračno imovinsko pravo u svjetlu Novele XX Lava Mudroga (s osobitim obzirom na razvoj bračnog imovinskog prava u srednjovjekovnim dalmatinskim gradskim općinama“, ZRVI XVIII, 1978., str. 45-47.

53 Davanje miraza postaje pravna, a ne moralna obveza. Gracijan je u Dekretu (dio II, ca. XXX, q. V, c. VI) ustanovio princip: ne sine dote fiat coniugum. Težak udarac institutu zadao je Inocent IV. koji je u komentaru Dekretu propisao matrimonium non probatur per instrumentum dotis. U Italiji princip nije naišao na širu primjenu. Vidi opširnije u Leicht, P. S., nav. dj,. str. 169.

54 Rapski statut, II, 14; Paški statut, V, 44; Šibenski diplomatarij, Šibenik, 1986., str. 150-155. U Šibeniku se 1292. g. odvijala parnica oko imovine pok. Slave de Soffe. Njena kći je tvrdila da joj je majka obećala 1000 libara i neku zemlju i tražila je da joj se ta imovina preda. Sud je presudio da majčino obećanje ne vrijedi, jer ona nije ništa donijela u miraz kad se udavala. Uz to se dodaje da su u vrijeme Slavine udaje mnoge Šibenčanke dobivale miraze od svojih očeva.

55 Korčulanski statut, gl. 124. Ref.

56 Dokoza, S., „Sustav dota u srednjovjekovnoj korčulanskoj komuni“, Godišnjak grada Korčule, 6. 2001., str. 24. 
i opis miraza, te vrijeme i način predaje miraza. Muž niti itko drugi nije mogao u ženino ime tražiti za nju od očevih ili majčinih dobara ništa poviše miraza. ${ }^{57}$

Temeljem mirazne isprave, žena i njeni nasljednici poslije su mogli zahtijevati izdvajanje miraza. Isprave o davanju miraza nisu sastavljane u svakom slučaju, o čemu doznajemo iz brojnih sporova o isplati miraza. Mnogobrojne sudske parnice svjedoče o tome da je isplata miraza bila čest uzrok parničenja. Miraz je najčešće davao otac budućem zetu ili njegovu ocu, a ponekad je i majka davala dio svoga miraza u prilog kćerinom mirazu. ${ }^{58}$ Dana 18. srpnja 1282. Nasennus, sin pok. Črnomira s Korčule, daje u ime miraza svoje kćeri Prvoslave njenom mužu kuću s pripacima koja je bila miraz njegove pokojne žene Regine, Prvoslavine majke, u skladu s dubrovačkim običajem. ${ }^{59}$

Nakon smrti roditelja, obvezu dotiranja djevojke preuzimala su braća. To je jasno vidljivo iz odredbe Korčulanskog statuta: ,... ako je neku kćer ili sestru udao otac, majka ili brat,... "60 pri čemu se riječ udao odnosi na davanje miraza djevojci. Ako ga nisu mogli isplatiti iz očeve i majčine imovine, morali su dati dio svojih dobara. U praksi su tu obvezu često izbjegavali, o čemu nam svjedoče sporovi. Braća su se brinula o udaji sestre i u slučaju njenog udovištva. Tada bi se miraz vraćao njenoj obitelji, a prilikom drugog vjenčanja bio bi predan novom suprugu. ${ }^{61}$

Predmet miraza na Korčuli najčešće je bila zemlja, zbog dominantne poljoprivrede, a rjeđe novac ili stoka. Tako je prosječni pučki miraz sadržavao 3-4 gonjaja zemlje, dijelom pod vinogradima, te 20-35 perpera. Notarski zapisi ukazuju nam na primjere zalaganja vinograda $u$ ime miraza. ${ }^{62}$

Kod miraza danih strancima novac je bio češće zastupljen od zemlje. Usporedba s ostalim dalmatinskim gradovima pokazuje da su korčulanski mirazi znatno siromašniji od onih u bogatijim dalmatinskim komunama. ${ }^{63}$ Jedna od osobina korčulanskog srednjovjekovlja bila je nedostatak većih količina gotova novca u optjecaju.

Među rijetkim primjerima primanja miraza u novcu nalazimo onaj od 24. veljače 1300. kada Bratko s Korčule potvrđuje primitak miraza od 100 perpera od svoje supruge Andriane, kćeri pok. Ljubiše, u skladu s dubrovačkim običajem. ${ }^{64}$

57 Korčulanski statut, gl. 113. nov. red.

58 Dokoza, S., nav. dj., 2001., str. 19.

59 Spisi dubrovačke kancelarije, prepisao i prepremio G. Čremošnik; knjiga I, Zapisi notara Tomazina de Savere (1278-1282), Zagreb, 1951., 1122/337.

60 Korčulanski statut, gl. 98. odnosno 113. nov. red.

${ }^{61}$ Dokoza, S., nav. dj., 2001., str. 21.

62 Spisi dubrovačke kancelarije, prepisao i prepremio G. Čremošnik; knjiga I, Zapisi notara Tomazina de Savere (1278-1282), Zagreb, 1951., 426/123.

63 Dokoza, S., nav. dj., 2001., str. 52.

${ }^{64}$ Spisi dubrovačke kancelarije IV, Zapisi notara Andrije Beneše (1295-1301), Zagreb, 1993., $161 / 54$. 
Notarski zapisi donose nam primjere davanja miraza iz dijela ukupne pokretne i nepokretne imovine. Dana 25. siječnja 1282. Desislav Milostić s Korčule daje u ime miraza svoje kćeri Slave Gregoriu iz Dubrovnika polovicu ukupne imovine. ${ }^{65}$

Statuti dalmatinske pravne regije najvećim dijelom dotirane djevojke ne smatraju podmirenima glede roditeljske ostavštine. To se uglavnom odnosi na odredbe sjevernodalmatinskih gradskih statuta: Zadarskog, Trogirskog, Šibenskog, Splitskog, Paškog, ali i Dubrovačkog. ${ }^{66}$ Upravo zbog toga nalazimo u notarskim spisima primjere odricanja udanih djevojaka od dijela koji bi im inače pripao. $\mathrm{Na}$ poseban način o tome govore Brački i Hvarski statut koji predviđaju udaju kćeri cum parte ili cum dote. ${ }^{67}$

Statuti Korčule, Lastova i Mljeta dotiranim djevojkama izričito odriču pravo na nasljeđivanje očeve i majčine imovine tj. udanu kći smatraju isplaćenom. ${ }^{68}$

\section{OBVEZNO PRAVO}

Glede sudjelovanja žena u privrednom životu grada, Korčulanski statut u reformacijama ograničava zarade pekarica i mlinarica. Reformacija 78. propisuje zaradu pekarica na način da dobiju samo jedan od 30 krušaca pod prijetnjom kazne od šest groša. Reformacijom 79 mlinaricama je zabranjeno naplaćivati više od 10 malih denara po kvarti. ${ }^{69}$

Velik broj sačuvanih isprava ukazuje na sudjelovanje žena u različitim pravnim poslovima među kojima se mogu izdvojiti poslovi vezani uz davanje zemlje u nasad (ad pastinandum) na način da žena sama daje zemlju u nasad ${ }^{70}$ ili pak da ženinu dotalnu zemlju u nasad daje muž pri čemu se javlja problem umanjivanja ženina miraza s obzirom na to da statut daje polovicu zemlje u trajno vlasništvo onome tko iskrči zemlju i na njoj posadi vinograd.

Jedna varijanta ovoga problema riješena je odlukom Velikog vijeća prema kojoj je mužu pripadala polovica zemlje ako je on iskrči i nasadi na njoj vinograd, a pretpostavlja se da se to odnosilo i na treće osobe kojima bi muž dao dotalnu zemlju na nasad i kojima bi pripala polovica nasađene zemlje. ${ }^{71}$

65 Spisi dubrovačke kancelarije, prepisao i prepremio G. Čremošnik; knjiga I, Zapisi notara Tomazina de Savere (1278-1282), Zagreb, 1951., 739/232.

66 Zadarski statut III, 127; Trogirski statut Ref. II, 223; Šibenski statut V, 25; Paški statut V, 21; Splitski statut III, 44; Dubrovački statut IV, 47.

67 Brački statut I, 23; Hvarski statut II, 32.

68 Korčulanski statut, gl. 98, 113 nov. red.; Lastovski statut, gl. 32; Mljetski statut, gl. 13.

69 Usp. Florence Fabijanec, S., „Gospodarska djelatnost žena na dalmatinskom komunalnom području od XIV. do XVI. stoljeća, Ženske skozi zgodovino“, Zbornik referatov 32. zborovanja slovenskih zgodovinarjev, Celje, 2004.,, str. 49-64; Florence Fabijanec, S., „Od tržnice do luke, Trgovačka svakodnevica kasnoga srednjeg vijeka“, Kolo - časopis Matice Hrvatske, br. 4, 2006., str. 188-214.

70 Dokoza, S., Dinamika otočnog prostora, Split, 2009., str. 73, 76, 80, 83.

71 Tako: Dokoza, S., „Sustav dota u srednjovjekovnoj korčulanskoj komuni“, Godišnjak grada Korčule, 6., 2001., str. 29. 


\section{NASLJEDNO PRAVO}

U nasljedom pravu Korčulanskog statuta dominira staro hrvatsko pravo, za razliku od rimskog i kasnijega hrvatsko-ugarskog prava Tripartita. ${ }^{72}$ Iz odredbe gl. 36. starije redakcije i gl. 39. nove redakcije Korčulanskog statuta može se zaključiti da kćerke imaju nasljedno pravo nakon smrti oca ako taj nije ostavio iza sebe mušku djecu, premda ti članci primarno određuju pravo reprezentacije unukama ako nemaju braće. Margetić naziva taj tip nasljednoga prava hrvatskim odnosno slavenskim tipom descendentskog nasljeđivanja, jer ga, osim na Korčuli, nalazi u Vinodolskom zakonu i u Poljičkom statutu, a sastoji se u tome što muški i ženski potomci odnosno srodnici mogu biti i nasljednici, pri čemu muški isključuju ženske. ${ }^{73}$

Odredbe Korčulanskog statuta nalažu ocu da svakom sinu ostavi jednak dio imovine.$^{74}$ Ustanova preferiranja djeteta na Korčuli bila je slabo razvijena, premda postupno s recepcijom rimskog prava i na Korčulu prodiru pravna shvaćanja o slobodnijem raspolaganju obiteljskom imovinom. ${ }^{75}$

Bezoporučno nasljeđivanje regulirano je odredbama gl. 40. starije redakcije, gl. 45. nove redakcije, te gl. 126. nove redakcije koja ih mijenja. Temeljem odredbi gl. 40. starije redakcije i gl. 45. nove redakcije, imovina pripada ocu, bratu, odnosno najbližem srodniku, dok temeljem gl. 126. nove redakcije imovina onoga tko umre bezoporučno pripada bližnjima po muškoj liniji, pri čemu muški isključuju ženske.

Primjena oporuke bila je ograničena zbog dominacije agnatskog načela i obiteljskog vlasništva, a kao preteču oporučnog raspolaganja Korčulanski statut poznaje institut preferiranja djeteta.

Korčulanski statut propisuje način sastavljanja pisane oporuke u gl. 147. reformacija, a o sastavljanju oporuka govore i gl. 41. starije redakcije te gl. 46. nove redakcije. Temeljem statutarnih odredbi, svatko je mogao oporukom ostaviti

72 Detaljnije: Cvitanić, A., „Korčulansko statutarno pravo“, u: Statut grada i otoka Korčule, priredio i preveo A. Cvitanić (ur. M. Foretić), Korčula, 2002., str. 43. Tripartit je pravni zbornik koji je sve do 1853. bio temeljnim izvorom građanskoga prava u zemljama Krune sv. Stjepana. Detaljnije: Pravni leksikon, Zagreb, 2007., str. 1632.; Lanović, M., Privatno pravo Tripartita, Zagreb, 1929.

73 Margetić, L., „O starom hrvatskom nasljednom pravu descendenata“, Historijski zbornik, god. XV-XVI., 1972-73., str. 273-279, isti: „Preferiranje djeteta po Krčkom, Rapskom i drugim primorskim statutima“, VHARP, sv. XVIII, Rijeka, 1973., str. 220, 232, 235; Cvitanić, A., „Usporedba Vinodolskog zakona i dalmatinskih statuta“, u: Cvitanić, A., Iz dalmatinske pravne povijesti, str. 707; Novak, Z., „Neki aspekti pravnog položaja ženâ u Vinodolskom zakonu, Senjskom i Krčkom statutu“, Historijski zbornik, god. LXII (2009.), br. 2., str. 339-341. Vinodolski zakon ima određenih sličnosti s Korčulanskim i Poljičkim statutom, jer im je podloga staro hrvatsko pravo, a u njegovu okruženju stoljeće poslije sastavljeni su Senjski statut i Krčki (Vrbanski) statut dok je Trsatskom zakonu bio podloga. Tako: Galović, T., ,Vinodolski zakonik - 725 godina poslije“, u: T. Galović, Z. Nikolić Jakus, Z. Janeković Römer, Ž. Radić, 725 godina Vinodolskog zakonika - 725 godina suzbijanja korupcije u Hrvaskoj, Zagreb, 2013. str. 8 .

74 Korčulanski statut, gl. 36. star. red.; gl. 39 nov. red.

75 Korčulanski statut, gl. 40. i 75. nov. red. Usp. Margetić, L., „Preferiranje djeteta po Krčkom, Rapskom i drugim primorskim statutima“, VHARP, sv. XVIII, Rijeka, 1973., str. 235. 
više sinovima nego kćerima, ali ne tako da jednom sinu ostavi više nego ostalim sinovima, ni jednoj kćeri više nego ostalim kćerima. ${ }^{76}$

Otac obitelji mogao je, nakon što djeci ostavi zakonski nužni dio, čitav četvrti dio imovine razdijeliti po svojoj volji. ${ }^{77}$

Ako braća ne bi htjela poudati svoje sestre nakon očeve smrti do njihove osamnaeste godine, one dobivaju dio očeve imovine obračunano po glavama, a ako nema sinova i braće, kćeri dijele nasljedstvo međusobno na jednake dijelove. ${ }^{78}$

Sinovi ili kćeri dviju supruga dijele međusobno na jednake dijelove očevu imovinu, ${ }^{79}$ a ako odu od oca bez njegova odobrenja, ne dobivaju ništa od očevih ili majčinih dobara. ${ }^{80}$

Žena je mogla raspolagati nekretninama na način da ih ostavi sinovima, kćerima ili mužu, dok je pokretninama mogla slobodno raspolagati. ${ }^{81}$

\section{KAZNENO PRAVO}

Među kaznenim djelima koja se odnose na žene, Korčulanski statut normira silovanje, čarobnjaštvo, ubojstvo, krađu, tučnjavu, uvredu itd.

Silovanje je jedan od učestalih vidova kriminala u komunalnim društvima. Skradinski ga statut naziva primum maleficium post omicidium, ${ }^{82}$ a zbog napada na temelje komunalnog života, strogo ga sankcioniraju svi dalmatinski statuti. ${ }^{83}$

Dubrovački statut kod ovog kaznenog djela pruža zaštitu ženama svih društvenih slojeva, propisujući jedinstvenu kaznu za silovanje. ${ }^{84}$ Kazneno djelo silovanja Zadarski i Paški statuti ne spominju. U svim drugim statutima (osim u Dubrovačkom

76 Korčulanski statut, gl. 37. Ref.

77 Korčulanski statut, gl. 131. Ref.

78 Korčulanski statut, gl. 36. star. red; gl. 39. nov. red.

79 Korčulanski statut, gl. 37. star. red; gl. 41. nov. red.

80 Korčulanski statut, gl. 145. Ref.

81 Korčulanski statut, gl. 75. nov. red. Za pokretnine vidi gl. 40. i 130. nov. red.; Vidi notu 93. na str. 116. Korčulanskog statuta.

82 Skradinski statut, cap. XCII, Šibenski statut, VI, 61-66.

83 O kaznenom djelu silovanja u dalmatinskom statuarnom pravu komparativno usp. Jaramaz Reskušić, I., Kazneni sustav u Šibeniku od 14. do 16. st., Šibenik, 1996., str. 53; Dinić-Knežević, D., nav. dj., str. 125; Cvitanić, A., nav. dj., str. 272.; Heršak, G., „Krivično djelo silovanja u Korčulanskom statutu i komparativno“, Zbornik radova Statut Korčule 1214., Zagreb - Samobor, 1989., str. 195-212.

84 Dubrovački statut, VI, 6. Detaljnije: Dinić-Knežević, D., Prilog iz života žena u srednjovekovnom Dubrovniku, Istraživanja, br. 13, Novi Sad, 1990., str. 68. Lastovski (gl. 15)ni Mljetski statut (gl. 15) ne poznaju staleške razlike kod kažnjavanja silovanja. Detaljnije: Pezelj V. - Štambuk Šunjić, M.: „Pravni položaj žene po Lastovskom statutu“, Zbornik radova Pravnog fakulteta Split, br. 3/2013 (109), str. 533; Pezelj, V., ,Pravni položaj žene prema Mljetskom statutu iz 1345. godine“, Liber amicorum, Zbornik radova posvećen Antunu Cvitaniću, Ž. Radić (ed.), Split, 2016., str. 327. 
gdje je kazna bila razmjerno mala i jednaka za sve, te u Lastovskom i Mljetskom statutu) kazna je za silovatelja ovisila o bračnom i društvenom statusu žene. ${ }^{85}$

Korčulanski je statut najprecizniji među južnim statutima glede određivanja kazne za silovanje s obzirom na različiti društveni položaj i obiteljski status oštećenice. Plemiću koji je silovao udanu plemkinju odsijecala se glava ako je djelo bilo dokazano s dva svjedoka. Za silovanje neudane plemkinje kazna je bila 100 dukata, od čega je polovica išla djevojci, a polovica općini. Pored toga, počinitelj je morao odležati u zatvoru šest mjeseci, a kaznu je mogao izbjeći ako bi se oženio oštećenicom. Na smrt odsijecanjem glave bio bi osuđen i plemić koji bi silovao udanu seljanku. Za silovanje neudane seljanke plemić je plaćao 50 dukata i bio kažnjen s tri mjeseca zatvorske kazne. Ako bi pak seljak silovao neudanu plemkinju, kažnjavan je vješanjem, a ako bi plemkinja nekoga lažno optužila za silovanje, bila bi kažnjena spaljivanjem. ${ }^{86}$ Kazna spaljivanja za plemkinju, kao i za seljanku koja bi lažno optužila seljaka za silovanje, propisana je samo novijom redakcijom Korčulanskog statuta.

Kod kaznenog djela čarobnjaštva odnosno crne magije ogleda se primitivnost tadašnjih shvaćanja, a ujedno je i primjer kažnjavanja bez kauzalnog neksusa. ${ }^{87}$ Srednjovjekovni statuti polaze od istog shvaćanja zločina čarobnjaštva. Dok većina statuta određuje kazne za herbariae, Korčulanski ${ }^{88}$ i Dubrovački ${ }^{89}$ uz navedeno pobliže određuju i njegov sadržaj. ${ }^{90}$ Postupci vođeni protiv osoba optuženih za ovo djelo nose obilježja karakteristična za inkvizicijske postupke protiv heretika vođene već od sredine 13. st. širom Europe. ${ }^{91}$

85 Korčulanski statut, gl. 11. star. red.; gl. 132. - 134. nov. red.; Dubrovački statut, VI, 6; Lastovski statut, gl. 15; Splitski statut, IV, 37; Šibenski statut, VI, 41-46; Rapski statut, IV, 66, 67; Trogirski statut, II, 21. Posebno je zanimljivo što, primjerice, Šibenski statut navedeno kazneno djelo regulira najpodrobnije od svih dalmatinskih statuta, dok Paški i Zadarski o njemu ne kažu ništa iako je stari nesačuvani Zadarski statut poslužio kao zajednički predložak za sva tri statuta.

86 Korčulanski statut, gl. 11. star. red.; gl. 132. - 134. nov. red. Usp. Foretić V., Studije i rasprave iz hrvatske povijesti, Split, 2001., str. 435.

87 Ovo kazneno djelo nalazimo u primitivnih naroda ranoga srednjeg vijeka. Alemani i Burgundi nazivaju žene koje se bave čarobnjaštvom herbariae. Rotarijev edikt (cap. 376) propisuje zabranu bavljenja magijom nad ljudima, propisujući tešku kaznu za to djelo. Po vizigotskom pravu i drugim germanskim pravima, delikti kao npr. bavljenje magičnim činima zbog prouzrokovanja abortusa imali su kao posljedicu pad u ropstvo. Leicht, P. S., Storia del diritto italiano, Diritto privato. Parte prima, Diritto delle persone e di famiglia, Milano, 1960., str. 38., Guerra Medici, M. T., nav. dj., str. 32.

88 Korčulanski statut, gl. 12. star. red.; gl. 17. nov. red. Usp. Ređep, J., „Moć vradžbine (razmišljanja povodom XVII gl. Korčulanskog statuta)", Zbornik radova znanstvenog skupa Statut grada $i$ otoka Korčule iz 1214. g., Zagreb - Samobor, 1989., str. 237-249.

89 Dubrovački statut, IV, 7.

90 Splitski statut, IV, 87; Trogirski statut, II, 26; Skradinski, cap. 76; Rapski statut IV, 51; Hvarski statut III, 10; Kotorski statut, cap. 101.; Cvitanić, A., „Usporedba Vinodolskog zakona i dalmatinskih statuta“, u: Cvitanić, A., Iz dalmatinske pravne povijesti, str. 707.

91 Vidi Bayer, V., Ugovor s đavlom, Zagreb, 1969., str. 103-114, 139-154, 223-224, 531-538.; Jaramaz-Reskušić, I., Kazneni sustav u Šibeniku od 14. do 16. st., Šibenik, 1996., str. 85; Novak, Z., „Neki aspekti pravnog položaja ženâ u Vinodolskom zakonu, Senjskom i Krčkom statutu“, Historijski zbornik, god. LXII (2009.), br. 2., str. 333. 
Kod kaznenog djela ubojstva, komuna je dužna ženi ubijenog pribaviti polovicu ubojičine imovine koja bude dopala Komuni. ${ }^{92}$

Statut kažnjava tučnjavu među ženama propisujući novčanu kaznu odnosno supsidijarno kaznu zatvora..$^{93}$ Ako kao posljedica udarca nastupi smrt, žena koja je nanijela udarac kažnjava se kao za ubojstvo, odnosno ako dođe do gubitka uda uslijed udarca, kazna se izriče prema statutarnoj glavi o gubitku udova.

Statut predviđa slučaj da „muškarac ili žena“ uputi uvredu sucima, vijećnicima ili drugim službenim osobama odnosno da izvrše druge zločine koji nisu unaprijed zapisani u statutu.$^{94} \mathrm{U}$ tom slučaju kazna nije unaprijed propisana već o njoj odlučuje knez s dvojicom iz Vijeća s kojima se bude htio posavjetovati. Ista se formulacija (,muškarac ili ženska“) upotrebljava i kod ulaženja u tuđu kuću, što se kažnjava novčanom kaznom, od koje polovica pripada onome kome je naneseno nasilje. ${ }^{95}$

Bludnica koja uputi pogrdne riječi ženi dobra glasa kažnjava se postavljanjem uz stup srama. ${ }^{96}$ Ta je kazna zamijenjena kaznom šibanja po ref. 29. iz 1397. godine. Ženu na zlu glasu koja vrijeđa poštenu ženu kažnjava se šibanjem u trku oko grada, a smatra se dovoljnim svjedočenje dviju žena. ${ }^{97}$

Ženska osoba koja ukrade neku krupnu životinju, a nema odakle platiti kaznu, kažnjavala se spaljivanjem. ${ }^{98}$

\section{PROCESNO PRAVO}

Temeljem statutarnih odredbi nitko (,nijedan muškarac ni žena“) nije mogao biti osuđen ako nije bio pozvan da se brani od strane komunalne uprave. ${ }^{99}$ Ako pozvani nije pristupio pred sud, bio je proglašen krivim za ono za što je optužen. Dokazni

92 Korčulanski statut, gl. 1. star. red. i gl. 1. nov. red.

93 Korčulanski statut, gl. 13. star. red.; gl. 18. nov. red. U slučaju tučnjave među ženama dovoljan je jedan svjedok za potpuni dokaz. Detaljnije: Tomašević, G. - Krstulović Dragičević, A. - Pleić, M., „Pravni položaj okrivljenika u kaznenom postupku dalmatinskih statuta“, u: Liber amicorum, Zbornik radova posvećen Antunu Cvitaniću, Ž. Radić (ed.), Split, 2016., str. 373, n. 93. Usp. Florence Fabijanec, S., „Od tržnice do luke, Trgovačka svakodnevica kasnoga srednjeg vijeka“, Kolo - časopis Matice Hrvatske, br. 4, 2006., str. 204; Z. Nikolić, „Neki aspekti pravnog položaja ženâ u Vinodolskom zakonu, Senjskom i Krčkom statutu“, Historijski zbornik, god. LXII (2009.), br. 2., str. 329 . O kazni zatvora u srednjem vijeku vidi Radić, Ž. - Pezelj, V., ,Funkcije zatvora (carcer) u dalmatinskom statutarnom pravu", u: Istražne radnje i pomoćna sredstva u sudskim postupcima kroz povijest, urednik M. Gardaš, Pravni fakultet Osijek, 2010., str. 117-138. Lastovski je statut poznavao poseban zatvor za žene. Lastovski statut, gl. 126. Detaljnije: Pezelj V. - Štambuk Šunjić, M.: „Pravni položaj žene po Lastovskom statutu“, Zbornik radova Pravnog fakulteta Split, br. 3/2013 (109), str. 533.

94 Korčulanski statut, gl. 21. star. red.

95 Korčulanski statut, gl. 59. nov. red i gl. 2. dodatka star. red.

96 Korčulanski statut, g1. 13. Ref.

97 Korčulanski statut, g1. 29. Ref.

98 Korčulanski statut, gl. 13. nov. red. Usp. gl. 144. Ref.

99 Korčulanski statut, gl. 128. nov. red. O arbitraži u Korčulanskom statutu vidi: Uzelac, A. - Krešić, M., „Arbitraža (izabrano suđenje) u Korčulanskom statutu i statutima istočne obale Jadrana“, u: Liber amicorum Gašo Knežević, Beograd, 2016., str. 347-372. 
Dr. sc. Vilma Pezelj i Marija Štambuk: Pravni položaj žene prema srednjovjekovnom Korčulanskom... Zbornik radova Pravnog fakulteta u Splitu, god. 55, 3/2018., str. 557.- 578.

su se postupci izvodili neposredno, što je omogućavalo logičku ocjenu dokaza. Ispitivanje svjedoka obavljalo se usmeno. ${ }^{100}$ Statutarna odredba Korčulanskog statuta nove redakcije ženi i maloljetnicima uskraćuje pravo biti svjedokom. ${ }^{101}$ Iznimka je kod kaznenog djela uvrede prema odredbama reformacija, kada se dopušta svjedočenje dviju žena. ${ }^{102}$

U pogledu svjedočke sposobnosti u kaznenim postupcima statuti su manje zahtjevni nego u građanskim postupcima, iako i u kaznenim postupcima pribjegavaju svjedočenju žena samo kod poteškoća u utvrđivanju činjenica. Tako npr. Trogirski ${ }^{103}$ i Splitski ${ }^{104}$ statut dopuštaju ženama svjedočenje u kaznenim postupcima, ali ne i u građanskim. Dubrovački statut diskriminira žene, određujući da se kod delikata počinjenih noću njihovo svjedočanstvo može prihvatiti tek ukoliko nema muških svjedoka, pa i onda se smije izreći kazna prepolovljene vrijednosti. ${ }^{105}$ Velik broj statuta kod delikata izvršenih noću predviđa ublaženi sistem zakonskih dokaznih pravila, jer bi inače mogućnost dokazivanja bila bitno otežana.

Tortura je u ono vrijeme bila općepoznato sredstvo za iznuđivanje priznanja, pa je nalazimo i u Korčulanskom statutu (za ženu koja optuži seljaka za silovanje). ${ }^{106}$

100 Tomašević, G. - Krstulović Dragičević, A. - Pleić, M., „Pravni položaj okrivljenika u kaznenom postupku dalmatinskih statuta“, u: Liber amicorum, Zbornik radova posvećen Antunu Cvitaniću, Ž. Radić (ed.), Split, 2016., str. 354.

101 Korčulanski statut, gl. 37. nov. red. Drugačije određuje gl. 34. star. red.

102 Korčulanski statut, gl. 29. Ref. Slično propisuje i Krčki statut. Detaljnije: Lonza, N., „Kazneni postupak Krčkog (vrbanskog) statuta iz 1388.“, Zbornik Pravnog fakulteta u Zagrebu, 43., br. 4., 1993., str. 719.

103 Trogirski statut, I, 46; Detaljnije, Cvitanić, A., „Neki elementi pravnog položaja žene u srednjovjekovnom Trogiru“, u: Iz dalmatinske pravne povijesti, Split, 2002., str. 299.

104 Splitski statut, III, 8. Detaljnije: Pezelj, V., „Pravni položaj žene po Splitskom statutu iz 1312. godine“, u Splitski statut iz 1312. godine: povijest i pravo, povodom 700. obljetnice, Zbornik radova s međunarodnoga znanstvenog skupa održanog 24. - 25. rujna 2012. godine u Splitu, Ž. Radić - M. Trogrlić - M. Meccarelli - L. Steindorff (eds.), Split, 2015., str. 248.

105 Dubrovački statut, VI, 33, 34. O problemu svjedočke sposobnosti žena, prema srednjovjekovnim vrelima v. Lonza, N., Regule o torturi i indicijama u zadarskom rukopisu iz XIV. stoljeća, magistarski rad, Zagreb, 1986., str. 70. Za druge statute po tom pitanju vidi Lonza, N., „Kazneni postupak Krčkog (vrbanskog) statuta iz 1388.“, Zbornik Pravnog fakulteta u Zagrebu, 43., 1993., str. 718.; Novak, Z., „Neki aspekti pravnog položaja ženâ u Vinodolskom zakonu, Senjskom i Krčkom statutu“, Historijski zbornik, god. LXII (2009.), br. 2., str. 334-338. Milović, Đ., „Pitanja kazneno-procesualnog prava u Vinodolskom zakonu i Trsatskom statutu iz 1640. g.“, u Liber amicorum, Zbornik radova posvećen Antunu Cvitaniću, Ž. Radić (ed.), Split, 2016., str. 236. Za talijanske statute usp. Bohne, G., Zur Stellung der Frau im Prozeß und Strafrecht der italienischen Statuten, Leipziger rechtswissenschaftliche Studien, Gedenkschrift für L. Mitteis, Weicher, Leipzig, 1926., str. 102.

106 Korčulanski statut, gl. 134. nov. red. Detaljnije: Lonza, N., „,Tortura u Korčulanskom statutu i sudskim zapisima XV. Stoljeća“, u: Zbornik radova Znanstvenog skupa Statut grada i otoka Korčule iz 1214. g., Zagreb - Samobor, 1989., str. 163-176.; ista: „Tortura u Korčulanskom statutu i sudskim zapisima XV. stoljeća“", u: Hrestomatija povijeti hrvatskog prva i države, sv. I., Zagreb, 1998., str. 197211. U Splitskom statutu trudna se žena nije smjela podvrći torturi zbog mogućeg oštećenja i gubitka ploda, a iz istog razloga morala se odgoditi smrtna kazna trudnici dok ne rodi. Usp. Splitski statut IV, 84, 85. O odgađanju torture trudnicama govori već Corpus iuris civilis: Ulp. Dig. 48. 19. 3., te Paulus, Sent. 1. 12. 4. Detaljnije: Fiorelli, P., La tortura giudiziaria nel diritto comune, vol. I, Milano, Giuffré, 1953., str. 295-299.; Pansolli, L., voce Tortura, Novissimo digesto italiano, vol. XIX, Torino, 1973., str. 424-425.; Tomašević, G., „Pregled nekih povijesnih rješenja o primjeni torture u kaznenom postupku“, Pogledi, 1/1984., str. 155-161; Tomašević, G. - Krstulović Dragičević, A. - Pleić, M., „Pravni položaj 


\section{ZAKLJUČAK}

Podređeni položaj žene u srednjovjekovnoj Korčuli proizlazi iz velikog broja odredbi Korčulanskog statuta. Udana je žena ograničeno poslovno sposobna. Za raspolaganje imovinom trebala joj je dozvola muža odnosno komunalne kurije. Udovica je uživala povoljniji položaj od udane žene, imala je pravo na dolično uzdržavanje o čijoj je visini odlučivala komunalna kurija. Ako se odlučila preudati, mogla je izdvojiti samo svoj miraz, a ako je ostala u udovištvu, imala je pravo uživati svoj miraz i muževu imovinu.

U obiteljskom pravu Korčulanske komune vidljiv je utjecaj kanonskog prava, stare romanske tradicije i hrvatske kulture. Po odredbama reformacija Korčulanskog statuta bilo je zabranjeno uzeti za suprugu djevojku ili ženu bez privole njenih najbližih krvnih srodnika. Ženina se imovina sastojala od njena miraza, pa ako se u slučaju udovištva odlučila preudati, smjela je uzeti samo svoj miraz, a ostalu imovinu ostaviti muževim potomcima. Premda je temeljem statutarne odredbe iz 1412. godine bilo potrebno o svakom mirazu sastaviti javnu ispravu u roku od jedne godine pod prijetnjom kazne, brojni sporovi o isplati miraza upućuju nas na zaključak da se u praksi ta odredba nije poštovala.

Koristeći ovlasti koje im je davao komunalni pravni poredak, žene su sudjelovale u privrednom životu grada. Iako statutarne odredbe spominju samo pekarice i mlinarice, iz sačuvanih notarskih zapisa saznajemo o sudjelovanju žena u različitim pravnim poslovima.

U nasljedom pravu dominira staro hrvatsko pravo, za razliku od rimskog $\mathrm{i}$ kasnijega hrvatsko-ugarskog prava Tripartita. Kćerke imaju nasljedno pravo nakon smrti oca ako on nije ostavio iza sebe mušku djecu. Tzv. hrvatski odnosno slavenski tip descedentskog nasljeđivanja, osim na Korčuli, prisutan je u Vinodolskom zakonu i Poljičkom statutu, a sastoji se u tome što muški i ženski potomci odnosno srodnici mogu biti i nasljednici pri čemu muški isključuju ženske. Za razliku od većine drugih statuta dalmatinske pravne regije, udana kći se na Korčuli, kao i na Lastovu i Mljetu, smatrala isplaćenom pa nije imala nasljedna prava prema ostavini roditelja.

Izrazito je nepovoljan status žena kod kaznenih djela silovanja i crne magije. Kod kaznenog djela silovanja, Korčulanski statut najpreciznije određuje kazne s obzirom na različiti društveni i obiteljski položaj žrtve, dok kod kaznenog djela čarobnjaštva Korčulanski, uz Dubrovački statut, jedini pobliže određuje njegov sadržaj. Među ostalim kaznenim djelima koja se odnose na žene valja izdvojiti tučnjavu među ženama, krađu, uvredu upućenu komunalnim službenicima, upad u tuđu kuću.

Statutarna odredba nove redakcije Korčulanskog statuta ženama uskraćuje pravo svjedočenja, osim kaznenog djela uvrede, kada je temeljem odredbe reformacija dopušteno svjedočenje dviju žena.

okrivljenika u kaznenom postupku dalmatinskih statuta“, u: Liber amicorum, Zbornik radova posvećen Antunu Cvitaniću, Ž. Radić (ed.), Split, 2016., str. 376-378. 
Među arhaične elemente Korčulanskog statuta koji se odnose na pravni položaj žene mogu se ubrojiti spolna diskriminacija, podvrgavanje žena torturi, kažnjavanje kaznenog djela čarobnjaštva itd.

Glede pravnog položaja žene, opravdano je govoriti o dodiru starih i novijih odredbi u statutu što je najjasnije vidljivo u odredbama dvije redakcije Korčulanskog statuta i u reformacijama. Odredbe novijeg datuma ukazuju na postupne pomake u pravnom položaju žene.

Pored statutarnih odredbi, slika korčulanskog statutarnog pravnog sustava upotpunjena je primjerima iz notarskih zapisa koji daju cjelovitiji uvid u srednjovjekovnu pravnu praksu. Statutarne odredbe koje predstavljaju normativnu stranu srednjovjekovnog pravnog sustava upotpunjene su na nekim mjestima primjerima sačuvanih dokumenata o konkretnim pravnim poslovima.

\section{LITERATURA:}

Arjava, A., Women and Law in Late Antiquity, Clarendon Press, Oxford, 1996.

Bartulović, Ž. - Ignjatović, M., „Widow enjoyment in Roman and Medieval Law (comparison with Venice, Frankish and „Istrian marriage“)“, The second International Balkan Conference for Roman Law and Roman Legal tradition „The Universality of Roman Law“, Ius Romanum 2/2017., str. 1-10.

Benyovsky Latin, I. - Pešorda Vardić, Z., Town and Cities of the Croatian Middle Ages, Zagreb, Hrvatski institut za povijest, 2014.

Besta, E., Le persone nella storia del diritto italiano, Padova, 1931.

Besta, E., La famiglia nella storia del dirito italiano, Milano, 1962.

Beuc, I., „Statut zadarske komune iz 1305. godine“, Vjesnik Državnog arhiva u Rijeci, sv. II, Rijeka, 1954., str. 493-781.

Birin, A., Statut grada Skradina, Statuta civitatis Scardonae, Uvodnu studiju napisao, Statut s latinskoga preveo i za tisak priredio A. Birin, Zagreb-Skrdin, 2002.

Blehova Ćelebić, L., Žene srednjovjekovnog Kotora, Podgorica, 2002.

Bogojević-Gluščević, N., „Legal regime of the property of married women in medieval Zeta littoral cities (Kotor, Budva, Shkoder)“", The second International Balkan Conference for Roman Law and Roman Legal tradition „The Universality of Roman Law“, Ius Romanum 2/2017., str. 1-23.

Bohne, G., Zur Stellung der Frau im Prozeß und Strafrecht der italienischen Statuten, Leipziger rechtswissenschaftliche Studien, Gedenkschrift für L. Mitteis, Weicher, Leipzig, 1926.

Budak, N., „Struktura i uloga obitelji serva i famula u komunalnim društvima na istočnom Jadranu“, Starohrvatska prosvjeta 14 (1984.) I, str. 347-361.

Budak, N., „Pravni položaj serva i famula u komunalnim društvima na istočnom Jadranu“, Radovi Instituta za hrvatsku povijest, Zagreb, 1986., str. 51-68. 
Bujuklić, Ž., Pravno uređenje srednjovekovne Budvanske komune, Nikšić, 1988.

Bujuklić, Ž., Forum romanum, Beograd, 2009.

$\mathrm{CD}=$ Codex diplomaticus regni Croatiae, Dalmatiae et Slavoniae, I - XVIII, Urednici T. Smičiklas (II-XII); E. Laszowski i M. Kostrenčić (XIII), M. Kostrenčić (I, XIV-XVI), S. Gunjača (XVII), D. Rendić-Miočević (XVIII). Zagreb, 1904-1990.

CD Suppl. = Codex diplomaticus, Supplementa, vol. I-II, Zagreb, 1998.

Cvitanić, A., Statut grada Splita, Splitsko srednjovjekovno pravo, Split, 1998.

Cvitanić, A., Iz dalmatinske pravne povijesti, Split, 2002.

Cvitanić, A., „Usporedba Vinodolskog zakona i dalmatinskih statuta“, u: Cvitanić, A., Iz dalmatinske pravne povijesti, Split, 2002., str. 701-714.

Cvitanić, A., Brački statut, Split, 2006.

Čučković, V., „Epitropi u starom dubrovačkom pravu“, Godišnjak PF u Sarajevu, god. 11 (1963.), str. 257-274.

Čučković, V., „O odredbi dubrovačkog statuta De concordio inter virum et uxorem schepatos (IV, 60)“, Godišnjak PF u Sarajevu, god. 25 (1977), str. 441-451.

Čučković, V., „Materijalno obezbjeđenje supružnika u dubrovačkom srednjovjekovnom pravu“, Godišnjak Pravnog fakulteta u Sarajevu, XXVIII, 1980., str. 307-338.

Dinić-Knežević, D., Položaj žena u Dubrovniku u XIII i XIV veku, SANU, posebna izdanja, odeljenje istoriskih nauka, Beograd, 1974.

Dinić-Knežević, D., Prilog iz života žena u srednjovekovnom Dubrovniku, Istraživanja, br. 13, Novi Sad, 1990., str. 61-73.

Dokoza, S., „Sustav dota u srednjovjekovnoj korčulanskoj komuni“, Godišnjak grada Korčule, 6., 2001., str. 17-53.

Dokoza, S., Dinamika otočnog prostora, Split, 2009.

Dubby, G. - Perrot, M., A History of Women in the West, Harvard, 1994.

Ennen, E., The Medieval Woman, Oxford, 1989.

Fiorelli, P., La tortura giudiziaria nel diritto comune, vol. I, Milano, Giuffré, 1953.

Finocchiaro-Sartorio, A., La comunione dei beni tra coniugi nella storia del diritto italiano, Palermo, 1902.

Florence Fabijanec, S., „Gospodarska djelatnost žena na dalmatinskom komunalnom području od XIV. do XVI. stoljeća, Ženske skozi zgodovino“, Zbornik referatov 32. zborovanja slovenskih zgodovinarjev, Celje, 2004., str. 49-64.

Florence Fabijanec, S., „Od tržnice do luke, Trgovačka svakodnevica kasnoga srednjeg vijeka“, Kolo - časopis Matice Hrvatske, br. 4, 2006., str. 188-228.

Foretić, V., Otok Korčula u srednjem vijeku do god. 1420., Rad JAZU, Zagreb, 1940.

Foretić, V., Povijest Dubrovnika do 1808. I, II, NZHH, Zagreb, 1980.

Foretić V., Studije i rasprave iz hrvatske povijesti, Split, 2001. 
Galović, T., ,Vinodolski zakonik - 725 godina poslije“, u: T. Galović, Z. Nikolić Jakus, Z. Janeković Römer, Ž. Radić, 725 godina Vinodolskog zakonika - 725 godina suzbijanja korupcije u Hrvaskoj, Zagreb, 2013., str. 7-13.

Gross, K. - Schüller, H. - Novak. M., Udžbenik ckrvenoga prava katoličke crkve, Zagreb, 1930.

Guerra Medici, M. T., I diritti delle donne nella societŕ altomedievale, Napoli, 1986.

Janeković-Römer, Z., Rod i grad, dubrovačka obitelj od XIII do XV stoljeća, Dubrovnik, 1994.

Janeković-Römer, Z., Maruša ili suđenje ljubavi, bračno-ljubavna priča iz srednjovjekovnog Dubrovnika, Zagreb, 2007.

Jaramaz-Reskušić, I., Kazneni sustav u Šibeniku od 14. do 16. stoljeća, Šibenik, 1996.

Kancelariski i notariski spisi 1278-1301, objavio: Gregor Čremošnik, Beograd, 1932.

Kaser, M., Das Römische Privatrecht, II, München, 1975.

Ketsch, P. - Kuhn, A., Frauen im Mittelalter, Band 2, Düsseldorf, 1984.

Ladić, Z., , Religioznost kao pokretač društvenih i intimnih promjena u srednjem vijeku primjer dominacije „,socijalnog i laičkog kršćanstva“ u urbanim društvima istočnojadranske obale, Religiousity as the Impetus of Social and Intimate Changes in the Middle Ages“, 7. istarski povijesni biennale, sv. 7, Poreč, 2017. (str. 78-109).

Lanović, M., Privatno pravo Tripartita, Zagreb, 1929.

Lefebvre-Teillard, A., Introduction historique au droit des personnes et de la famille, Paris, 1996.

Leicht, P. S., Storia del dirito italiano. Il diritto privato. Parte seconda. Diritti reali e di successione, Milano, 1943.

Leicht, P. S., Storia del dirito italiano. Il diritto privato. Parte prima, Diritto delle persone e di famiglia, Milano, 1960.

Lexicon latinitatis medii aevi Yugoslaviae, sv. I-VI, Zagreb, 1969-1978.

Lonza, N., Regule o torturi i indicijama u zadarskom rukopisu iz XIV. stoljeća, magistarski rad, Zagreb, 1986.

Lonza, N., „Kazneni postupak Krčkog (vrbanskog) statuta iz 1388.“, Zbornik Pravnog fakulteta u Zagrebu, 43., br. 4., 1993.

Lonza, N., „Na marginama rukopisa Lastovskog statuta iz 16. st.“, Anali Dubrovnik 36 (1998.), str. 7-32.

Lonza, N., „Tortura u Korčulanskom statutu i sudskim zapisima XV. stoljeća“, u: Hrestomatija povijeti hrvatskog prva i države, sv. I., Zagreb, 1998., str. 197-211.

Lučić, J., Obrti i usluge u Dubrovniku do početka XIV. stoljeća, Zagreb, 1979.

Margetić, L., „Nasljedno pravo descendenata po srednjovjekovnim statutima Šibenika, Paga, Brača i Hvara“, ZPFZ, XXII - broj 3 (1972.), str. 339-366.

Margetić, „O starom hrvatskom nasljednom pravu descendenata“, Historijski zbornik, god. XV-XVI., 1972./73., str. 273-279. 
Margetić, L., „Preferiranje djeteta po Krčkom, Rapskom i drugim primorskim statutima“, VHARP, sv. XVIII, Rijeka, 1973., str. 215-247.

Margetić, L., „Bizantsko bračno imovinsko pravo u svjetlu Novele XX Lava Mudroga (s osobitim obzirom na razvoj bračnog imovnskog prava u srednjovjekovnim dalmatinskim gradskim općinama“, ZRVI XVIII, 1978., str. 19-50.

Margetić, L., Srednjovjekovno hrvatsko pravo - Stvarna prava, Zagreb-Rijeka-Čakovec, 1983.

Margetić, L., „Mletačka repromissa, “dar u ponedjeljak” i grosina (pellicia vidualis)“, Zbornik radova Pravnog fakulteta u Zagrebu, XXIX, 1989., str. 163-172.

Margetić, L., Hrvatsko srednjovjekovno obiteljsko i nasljedno pravo, Zagreb, 1996.

Margetić, L., Srednjovjekovno hrvatsko pravo - Obvezno pravo. Zagreb-Rijeka, 1997.

Margetić, L., L'esecutore testamentario nei più antichi testamenti dalmati, Studi in onore di A. Biscardi, III, Milano, 1982.

Margetić, L., Perspektive daljnjeg rada na srednjovjekovnim statutima, Rad HAZU, knj. 482, 2001., str. 1-53.

Marinović, A., „Lopudska universitas, Pravni položaj otoka Loupuda u Dubrovačkoj Republici“, Anali Historijskog instituta u Dubrovniku; godina III, Dubrovnik 1954.

Milović, Đ., „Pitanja kazneno-procesualnog prava u Vinodolskom zakonu i Trsatskom statutu iz 1640. g.“, u Liber amicorum, Zbornik radova posvećen Antunu Cvitaniću, Ž. Radić (ed.), Split, 2016. (str. 223-250).

Mosher Stuard, S., A State of Deference: Ragusa / Dubrovnik in the Medieval Centuries (The Middle Ages Series), University of Pennsylvania Press, 1992.

Novak, G., Prošlost Dalmacije, Zagreb, 2001.

Novak, Z., „Neki aspekti pravnog položaja ženâ u Vinodolskom zakonu, Senjskom i Krčkom statutu“, Historijski zbornik, god. LXII (2009.), br. 2., str. 315-343.

Pansolli, L., voce Tortura, Novissimo digesto italiano, vol. XIX, Torino, 1973., str. 424-425.

Pederin, I., Jadranska Hrvatska u povijesti starog europskog bankarstva, Split, 1996.

Perinčić, T., „Prodaja roblja na Jadranu u 17. stoljeću“, Miscellanea Hadriatica et Mediterranea, vol. 1, no. 1, 2013., str. 109-120.

Pezelj, V., „Naznake pravnog položaja žene u sednjovjekovnom Zadru“, Zbornik radova Pravnog fakulteta u Splitu, god. 43 - br. 3-4/2006 (83), str. 523-551.

Pezelj, V., „Pravni položaj žene u Paškom statutu 1433.“, Anali Pravnog fakulteta u Beogradu, god. LVIII 1/2010., str. 168-194.

Pezelj, V., „Pravni položaj žene u srednjovjekovnom Šibeniku“, Zbornik radova „Mustafa Imamović, 45 godina naučnog i publicističkog rada“, Posebna izdanja, Knjiga 6, Sarajevo/Gradačac, 2010., str. 175-198.

Pezelj, V., „Pravni položaj žene u srednjovjekovnom Rapskom statutu“, Zbornik radova Pravnog fakulteta u Splitu, god. 48 (2011.), broj 1 (99), str. 73-87. 
Pezelj V. - Štambuk Šunjić, M.: „Pravni položaj žene po Lastovskom statutu“, Zbornik radova Pravnog fakulteta Split, br. 3/2013 (109), str. 525-539.

Pezelj, V., „Pravni položaj žene po Splitskom statutu iz 1312. godine“, u Splitski statut iz 1312. godine: povijest i pravo, povodom 700. obljetnice, Zbornik radova s međunarodnoga znanstvenog skupa održanog 24-25. rujna 2012. godine u Splitu, Ž. Radić - M. Trogrlić - M. Meccarelli - L. Steindorff (eds.), Split, 2015., str. 227-253.

Pezelj, V., „Pravni položaj žene prema Mljetskom statutu iz 1345. godine“, Liber amicorum, Zbornik radova posvećen Antunu Cvitaniću, Ž. Radić (ed.), Split, 2016. (str. 317-336).

Pravni leksikon, Zagreb, 2007., str. 1632.

Radić, Ž., Imovinsko pravo po statutu grada Trogira iz 1322. godine (doktorska disertacija), Split, 2002.

Radić, Ž. - Pezelj, V., „Funkcije zatvora (carcer) u dalmatinskom statutarnom pravu“, u: Istražne radnje i pomoćna sredstva u sudskim postupcima kroz povijest, urednik M. Gardaš, Pravni fakultet Osijek, 2010., str. 117-138.

Roberti, M., Le origini romano-christiane della comunione dei beni fra coniugi, Torino, 1919.

Roberti, M., Svolgimento storico del diritto privato in Italia, vol. I, CEDAM, Padova, 1935.

Roller, D., Dubrovački zanati u 15 i 16. st., Zagreb, 1951.

Roller, D., „Agrarno-proizvodni odnosi na području Dubrovačke republike od 13. do 16. st.“, Građa za gospodarsku povijest Hrvatske 5, Zagreb, 1955.

Sindik, I., Komunalno uređenje Kotora, Beograd, 1951.

SDK I = Spisi dubrovačke kancelarije, prepisao i prepremio G. Čremošnik; knjiga I, Zapisi notara Tomazina de Savere (1278-1282), Zagreb, 1951.

SDK II = Spisi dubrovačke kancelarije, prepisao i pripremio J. Lučić; knjiga II, Zapisi notara Tomazina de Savere (1282-1284), Zagreb, 1984.

SDK III = Spisi dubrovačke kancelarije, Zapisi notara Tomazina de Savere (1284-1286), Zagreb, 1988.

SDK IV = Spisi dubrovačke kancelarije, Zapisi notara Andrije Beneše (1295-1301), Zagreb, 1993.

Srednjovjekovni zakoni i opći akti na Kvarneru, priredio L. Margetić, Zagreb-Rijeka, 2012.

Tenšek, T. Z., Krstjani i trgovina robljem na Sredozemlju između 13. i 15. st., Fenomen „Krstjani“ u srednjovjekovnoj Bosni i Humu, Sarajevo, 2005., str. 309-354.

Tomašević, G. - Krstulović Dragičević, A. - Pleić, M., „Pravni položaj okrivljenika u kaznenom postupku dalmatinskih statuta“, u: Liber amicorum, Zbornik radova posvećen Antunu Cvitaniću, Ž. Radić (ed.), Split, 2016., str. 351-382.

Tomašević, G., „Pregled nekih povijesnih rješenja o primjeni torture u kaznenom postupku“, Pogledi, 1/1984., str. 155-161. 
Uzelac, A. - Krešić, M., „Arbitraža (izabrano suđenje) u Korčulanskom statutu i statutima istočne obale Jadrana“, u: Liber amicorum Gašo Knežević, Beograd, 2016., str. 347-372.

Vaccari, P., Il regime della comunione dei beni nel matrimonio rispetto all'Italia, Pavia, 1908.

Zbornik radova znanstvenog skupa Statut grada i otoka Korčule iz 1214. g., Zagreb Samobor, 1989.

\section{LEGAL POSITION OF WOMEN IN THE MEDIEVAL STATUTE OF KORČULA}

The authors analyze some questions on the legal position of women in the medieval Korčula, pointing to solutions in the other Dalmatian legal systems. This paper addresses the issues of the legal position of women in status, family (with marriage), property, criminal and procedural law.

The tendency of community authorities to prevent foreigners from gaining property and to prevent the division of family property by dowry were the fundamental causes for the inferior position of women in communal legal systems.

The statute of Korčula displays a Slavic legal base with the elements of Byzantine and Venetian law. During the reception of Roman law, some elements of the Roman law from Justinian's codification in glossarist and post-glossarist processing were adopted indicating the existence of interaction of legal cultures in the medieval Dalmatian communes.

Key words: legal position of women, Statute of Korčula, 13 th century, Dalmatian statutory law. 